\title{
Enterobacteriaceae in Some Imported Fish
}

\author{
Samaha IA and Hendawy TA* \\ Faculty of Veterinary Medicine, Alexandria University, Egypt
}

Submission: June 29, 2017; Published: September 27, 2017

*Corresponding author: Hendawy TA, Faculty of Veterinary Medicine, Alexandria University, Egypt, Email: dr_tarekhendawy@hotmail.com

\begin{abstract}
A total of 200 random samples of imported fishes represented by Bangasius hypophanmus (Basa), mullus surmuletus (Barboni), Saurida undosquamis (Mackerel) and Sparus aurata (Denise) (50 of each) which were collected from different markets at Alexandria province, for detection of enteropathogenic E.coli, Salmonellae, Shigella, Yersinia enterocolitica, Vibro parahaemolyticus, and Aeromonas. The current study had been done from March 2014 to February 2015. E. coli incidence was (21) 42\%, (18) 36\%, (19) 38\%, and (13) 26\% in examined samples of Basa, Barboni, Mackerel and Denis, respectively. Incidence of Salmonella was (3) 6\%, (5) 10\%, (4) 8\% and (2) 4\% of the examined samples of Basa, Barboni, Mackerel and Denise, respectively. Incidence of Shigella which was (13) 26\%, (11) 22\%, (14) $28 \%$ and (9) 18\% of the examined samples of Basa, Barboni, Mackerel and Denise, respectively. Incidence of Yarsinia which was (23) 46\%, (21) 42\%, (18) 36\% and (16) 32\% of the examined samples of Basa, Barboni, Mackerel and Denise, respectively. Incidence of Vibrio spp. was (15) 30\%, (14) 28\%, (13) 26\% and (11) 22\% of the examined samples of Basa, Barboni, Mackerel and Denise, respectively. Finally, incidence of Aeromonas hydrophilia was (8) 16\%, (11) 22\%, (8) $16 \%$ and (6) $12 \%$ of the examined samples of Basa, Barboni, Mackerel and Denise, respectively. Also, serological tests had been done for each microorganism to identify the incidence of specific strains. The public health significance of contaminants and the possible sources of contamination of imported fishes with these organisms as well as suggestive hygienic measures to improve the quality of such fishes were discussed.
\end{abstract}

Keywords: Imported fish; Enteropathogenic E.coli; Salmonellae; Shigella; Yersinia enterocolitica; Vibro parahaemolyticus; Aeromonas

\section{Introduction}

Unlike meat and poultry, fish are more liable to contamination with pathogenic bacteria from human reservoir which may contaminate the water depending on the fishing and also may be further contaminated during handling, processing and packaging. While the muscle flesh of fish, which is the main edible part is normally sterile but microorganisms can penetrate from the skin and the gut to the flesh, the penetration and contamination increase in case of fish caught from polluted area where there are high densities of bacteria. Singh \& Kulshrestha [1] isolated 17 strain of E.coli from fresh and marine fish, shrimp and mollusk fish which positive for enterotoxogenicity. Edris [2] Samples collected from Cairo and Giza supermarkets included (Mackerel, Sardine, Sardinella, fish burger and breaded shrimp). Such quality control was evaluated through organoleptical, microbiological and chemical examinations of 30 random samples of each fish and fish products. The present investigation proved that the examined random samples of the imported fish and fish products were quite safe for human E. coli and Salmonella were not isolated from all the examined samples. Ahmed [3] 62 samples of chilled fish fillets, 50 samples of iced peeled shrimp and 15 samples each of frozen imported and local peeled shrimp samples were collected from Cairo and Giza markets. Examined samples for isolation and identification of specific pathogens Vibrio spp., E. coli, Listeria spp., A. hydrophila, S. aurerus and $Y$. enterocolitica, Salmonella and Shigella. About $82.3 \%$ of filets samples were accepted according to the ESS (3494/2005), while $72 \%$ of peeled shrimp samples were accepted according to ESS (516/1993), whereas, 100 and 93\% of frozen imported and local shrimp samples were accepted. E. coli were isolated from fillets and peeled shrimp samples. Khadega [4] isolated Salmonella from $10 \%$ and $16 \%$ from Mullus and Basa while she failed to isolate Salmonella from Barboni. Elhadi [5] examined 35 samples and found 11 samples contaminated with Salmonella (31.4\%). Morris et al. [6] examined samples of fish immediately after catching where they failed to isolate Salmonella. But after they arrived to the plants, they could isolate this organism. Based on Morris's research imported fish contaminated during transportation, packaging and handling process. Onyango [7] among 120 imported Basa, 63 (52.5\%) were infected with Enterobacteriaceae. Out of these, 25 (39.7\%) were Shigella spp, 9 (14.3\%) Salmonella typhimurium, 7 (11.1\%) S. typhi, 4 (6.3\%) S. enteritidis, 16 (25.4\%) Escherichia coli, 1 (1.6\%) Proteus spp. and Enterobacter aerogenes, respectively. Ten fish collected from 
open-air markets yielded E. coli (50\%), S. typhimurium (20\%), S. paratyphi (10\%) and S. typhi (20\%). El-Leboudi [8] examined 15 imported fish samples, the author isolated 2 of Yersinia enterocolitica strains (13.3\%) from imported fish. Harydi [9] a total of 675 imported frozen fish samples from different origins were collected on arrival to Sokhna port, Suez city, Egypt. The prevalence of Salmonella spp. were found to be $(1.6 \%)$ in whole shrimp, (3.7\%) in peeled shrimp, (2.0) in whole fish fillets, and $(1.67 \%)$ in sepia, respectively. Meanwhile in calamari; Salmonella prevalence was found to be $4.0 \%$. Alzainy [10] examined 60 samples of frozen imported fish and live fish, $65 \%$ of samples were found to be positive for Aeromonas hydrophila isolation $76.6 \%$ were in life fish samples and $53.3 \%$ in frozen fish $94.87 \%$ exhibited $\alpha$ and $\beta$ hemolysis, $100 \%$ of life fish isolates show $\beta$ hemolysis while frozen fish isolates show $85.7 \% \beta$ hemolysis and $14.3 \% \alpha$ hemolysis, $97.43 \%$ of isolates show cytotoxic effect on Vero cells the highest frequency occur in the isolates of life fish group $60.50 \%$. Farag [11] Sixty two samples of chilled fish fillets, 50 samples of iced peeled shrimp and 15 samples each of frozen imported and local peeled shrimp samples were collected from Cairo and Giza markets bacteria counts for Aeromonas spp and vibrio spp. Were positive. Sharma [12] the research has shown that imported fish is most frequently and most extensively contaminated with bacteria from the Aeromonas genus (positive samples ranging from $37 \%$ to $93 \%$ ). El Noby [13] Sixty samples (20 each of Tilapia sp., Mugil cephalus and frozen mackerel fish samples) were randomly collected from different local shops of fish sailing and fish retailers of different sanitation levels at Zagazig city. Collected samples were examined bacteriologically for determination of the incidence as well as the count of psychrotrohic microorganisms using the rapid method 25 pOCI 24 hours) following by pour plate technique. The obtained results revealed that. The mean count of Aeromonas was $5.7 \times 10) \pm 3.0 \times 102,1.0 \times 105 \pm 4.9 \times 104$ and $3.3 \times 105 \pm 2.7 \times 104 \mathrm{cfu} / \mathrm{g}$ of examined Tilapia nilotica, Mugil cephalus and frozen Mackerel samples, respectively.

\section{Materials and Methods}

\section{Materials}

Collection of samples: A total of 200 random samples of imported fishes represented by Bangasius hypophanmus (Basa), mullus surmuletus (Barboni), Saurida undosquamis (Mackerel) and Sparus aurata (Denise) (50 of each) were collected from different fish markets in Alexandria city. Each sample (250g) was kept in a separate plastic bag and transferred directly with a minimum of delay to the laboratory of food hygiene department, Faculty of Veterinary Medicine, Alexandria University in an insulating refrigerated container under complete aseptic condition to avoid any changes in the quality of the sample. Samples were examined bacteriologically immediately after arrival to the laboratory for isolation and identification of Salmonella, Escherichia coli, Shigella, Vibrio parahaemolyticus, Yersinia enterocolitica and Aeromonas.
Culture media: EMB medium (HIMEDIA), XLD agar (Acumedia), MacConkey, Agar (BBL), Nutrient Agar (Difco), Semisolid agar (Difco), Thiosulfate-citrate-bile salt-sucrose agar (TCBS Agar) (BBL), M-Aeromonas Selective Agar Base (Havelaar) (Himedia) with ampicillin vial, Cefsulodin-irgasan-novobiocin (CIN) agar (Oxoid), Trypticase Soy Broth, Bile-Oxalate-Sorbose broth and MacConkey's broth.

\section{Methods}

25 grams of each fish fillet sample were aseptically transferred into sterile blender flask containing $225 \mathrm{ml}$ of sterile peptone water $0.1 \%$ and homogenized at $1400 \mathrm{rpm}$ for $2-5$ minutes to provide a homogenate $1 / 10$ dilution and then allowed to stand for about 6 minutes at room temperature. The contents of the flask were thoroughly mixed by shaking and one $\mathrm{ml}$ of the homogenate was transferred with sterile pipette to another tube containing $9 \mathrm{ml}$ of sterile peptone water, from which tenth fold serial dilutions were prepared up to 10-6 (APHA, 1985) [14].

1.Isolation and identification of Salmonellae: According to (Rappaport \& Harvy and Price) [15,16], (Collins \& Cruickshank) [17,18], (Simmon) [19], (Kovacs) [20], (Ljutov) [21], (MacFaddin) [22], (Hugh \& Leifson) [23], (Edwards \& Ewing) [24], (Kauffman) [25] for serological examination, and (ICMSF, 1996) [26] for preenrichment.

2. Isolation and identification of Escherichia coli: According to (Rappaport \& Harvy) [15,16], (Collins \& Cruickshank) [17,18], (Simmon) [19], (Kovacs) [20], (Ljutov) [21], (MacFaddin) [22], (Hugh \& Leifson) [23], and (Edwards \& Ewing) [24].

3. Isolation and identification of Shigella: According to (Rappaport \& Harvy) [14,15], (Collins \& Cruickshank) [17,18], (Simmon) [19], (Kovacs) [20], (Ljutov) [21], (MacFaddin) (Hugh \& Leifson) [23], and (Edwards \& Ewing) [24].

4. Isolation and identification of Yersinia: According to (Schiemann, 1983)[27] for Pre-enrichment, Krieg \& Holt [28] and (MacConkey) [29] for selective enrichment and plating.

5. Isolation and identification of Vibrio parahaemolyticus: According to (APHA) [30].

6. Isolation and identification of Aeromonas: According to (Havelaar) [31].

7. The obtained results were statistically evaluated according to the guidelines recommended by Feldman et al. [32].

\section{Discussion}

Literature extended over many years pointed out that fish and its products are liable to contamination with various kinds of micro-organisms from different sources. Such contamination may render the fish unsafe to the consumers or impair its utility, especially in undeveloped countries, where the hygienic measures are still underway. Many efforts were done to keep the fish free from pathogens of public health hazard. 


\section{Isolation of enteropathogenic $E$. coli}

Table 1: Incidence of Enteropathogens in the examined samples of imported fishes $(\mathrm{N}=50)$.

\begin{tabular}{|c|c|c|c|c|c|c|c|c|}
\hline & \multicolumn{2}{|c|}{ Basa } & \multicolumn{2}{|c|}{ Barboni } & \multicolumn{2}{|c|}{ Mackerel } & \multicolumn{2}{|c|}{ Denise } \\
\hline & No. & $\%$ & No. & $\%$ & No. & $\%$ & No. & $\%$ \\
\hline Salmonella & 3 & 6 & 5 & 10 & 4 & 8 & 2 & 4 \\
\hline E.coli & 21 & 42 & 18 & 36 & 19 & 38 & 13 & 26 \\
\hline Shigella spp. & 13 & 26 & 11 & 22 & 14 & 28 & 9 & 18 \\
\hline Yersiniaspp. & 23 & 46 & 21 & 42 & 18 & 36 & 16 & 32 \\
\hline Vibrio spp. & 15 & 30 & 14 & 28 & 13 & 26 & 11 & 22 \\
\hline $\begin{array}{c}\text { Aeromonas } \\
\text { hydrphilie }\end{array}$ & 8 & 16 & 11 & 22 & 8 & 16 & 6 & 12 \\
\hline
\end{tabular}

It was evident from the results recorded in (Table 1), enteropathogenic E. coli was isolated from (21) 42\%, (18) $36 \%$, (19) $38 \%$ and (13) $26 \%$ of the examined samples of $S$ Bangasius hypophanmus (Basa), mullus surmuletus (Barboni), Saurida undosquamis (Mackerel) and Sparus aurata (Denise), respectively. This result was not compatible with the Egyptian standards (E.S889/2009) [33] of frozen fish, part 1 whole fish that stated that fish must be free from E. coli. The current result of isolation of $E$. coli from the examined samples of imported fish was higher than those obtained by Singh \& Kulshrestha [1] who could isolate 17 strains from all examined samples. Also, our results for Mackerel is contradict the result obtained by Edris [2] who stated that E.coli was quite safe for human consumption according to his results. As well as Ahmed [3] who examined 15 samples of imported fish and stated that it is accepted for (E.S889/2009) [32]. Serotyping of enteropathogenic E.coli isolated from the examined samples of imported fish was declared in Table 2.

Table 2: Serotyping of E.coli isolated from the examined samples of imported fishes $(n=50)$.

\begin{tabular}{|c|c|c|c|c|c|c|c|c|c|}
\hline & \multicolumn{2}{|c|}{ Basa } & \multicolumn{2}{|c|}{ Barboni } & \multicolumn{2}{|c|}{ Mackerel } & \multicolumn{2}{|c|}{ Denise } & \multirow[t]{2}{*}{ Strain character } \\
\hline & No. & $\%$ & No. & $\%$ & No. & $\%$ & No. & $\%$ & \\
\hline 086:K61(B7) & 4 & 8 & 6 & 12 & 3 & 6 & 3 & 6 & EPEC \\
\hline 0111:K58(B9) & 3 & 6 & 2 & 4 & 6 & 12 & - & - & EHEC \\
\hline 0124:K72(B17) & 4 & 8 & 1 & 2 & 3 & 6 & 4 & 8 & EIEC \\
\hline 026:K60(B6) & 5 & 10 & 4 & 8 & 3 & 6 & 2 & 4 & EHEC \\
\hline 0128:K67(B12) & 5 & 10 & 5 & 10 & 4 & 8 & 4 & 8 & ETEC \\
\hline Total & 21 & 42 & 18 & 36 & 19 & 38 & 13 & 26 & \\
\hline
\end{tabular}

Table 2 Serotyping of E.coli isolated from the examined samples of imported fishes stated 5 strains of $E$. coli isolated from Basa, Barboni and Mackerel, as 086:K61 (B7), 0111:K58 (B9), 0124:K72 (B17), 026:K60(B6), and 0128:K67(B12). Furthermore, 4 strains were serologically isolated from Denise as 086:K61 (B7), 0124:K72 (B17), 026:K60 (B6), and 0128:K67 (B12). The result in (Table 2) shows the percentage of the incidence for each strain as follow, for 086:K61(B7) it was (4) $8 \%$, (6) $12 \%$, (3) $6 \%$, and (3) $6 \%$ of the examined samples of $S$ Bangasius hypophanmus (Basa), Mullus surmuletus (Barboni), Saurida undosquamis (Mackerel) and Sparus aurata (Denise), respectively. Secondly, incidence of 0111:K58(B9), was (3) 6, (2) 4, (6) 12, and zero in the examined samples of $S$ Bangasius hypophanmus (Basa), Mullus surmuletus (Barboni), Saurida undosquamis (Mackerel) and Sparus aurata (Denise), respectively. Thirdly, incidence of 0124:K72 (B17) was (4) 8, (1) 2, (3) 6, and (4) 8 in the examined samples of $S$ Bangasius hypophanmus (Basa), Mullus surmuletus (Barboni), Saurida undosquamis (Mackerel) and Sparus aurata (Denise), respectively. As well as, the incidence of 026:K60 (B6), was (5) 10, (4) 8, (3) 6, and (2) 4 in the examined samples of $S$ Bangasius hypophanmus (Basa), Mullus surmuletus (Barboni), Saurida undosquamis (Mackerel) and Sparus aurata (Denise), respectively. Finally, incidence of 0128:K67 (B12) was (5) 10, (5) 10, (4) 8, and (4) 8 in the examined samples of $S$ Bangasius hypophanmus (Basa), Mullus surmuletus (Barboni), Saurida undosquamis (Mackerel) and Sparus aurata (Denise), respectively. Nearly similar results were reported by Donenberg \& Kaper [33,34].

\section{Salmonella}

Table 3: Serotyping of Salmonella organisms isolated from the examined samples of imported fishes (No.50).

\begin{tabular}{|c|c|c|c|c|c|c|c|c|}
\hline & \multicolumn{2}{|c|}{ Basa } & \multicolumn{2}{c|}{ Barboni } & \multicolumn{2}{c|}{ Mackerel } & \multicolumn{2}{c|}{ Denise } \\
\hline & No. & $\%$ & No. & $\%$ & No. & $\%$ & No. & $\%$ \\
\hline S.enteritidis & 1 & 2 & 1 & 2 & 2 & 4 & 1 & 2 \\
\hline S.typhimurium & - & - & 1 & 2 & 1 & 2 & - & - \\
\hline S.paratyphi & - & - & 1 & 2 & 1 & 2 & - & - \\
\hline S.haifa & 2 & 4 & 2 & 4 & - & - & 1 & 2 \\
\hline Total & 3 & 6 & 5 & 10 & 4 & 8 & 2 & 4 \\
\hline
\end{tabular}


The recorded results in Table 3 stated incidence of Salmonella which was (3) 6\%, (5) 10\%, (4) 8\% and (2) 4\% of the examined samples of Basa, Barboni, Mackerel and Denise, respectively. This result was not compatible with the Egyptian standards (E.S889/2009) [33] of frozen fish that stated that fish must be free from Salmonella in 25g. These results were in harmony with that of Khadega [4] who could isolate Salmonella from $10 \%$ and $16 \%$ from Mullus and Basa while she failed to isolate Salmonella from Barboni. Also, Salmonella organisms were previously isolated from imported fish by Stevens et al. [35], Baquar et al. [36] and Dalsgaarg [37]. Elhadi [5] his result higher than our result in Mackerel, he examined 35 samples and found 11 samples contaminated with Salmonella (31.4\%), whereas, we found only 4 out of 50 Mackerel samples (8\%). We found Salmonella in 4 samples 8\% of Mackerel, while Edris [2] couldn't find Salmonella in (30) examined Mackerel samples. As well as Ahmed [3] who stated that 15 samples of imported fish were free from Salmonella. It is important to mention that Morris et al. [6] examined samples of fish immediately after catching where they failed to isolate Salmonella. But after they arrived to the plants, they could isolate this organism. Based on Morris's research imported fish contaminated during transportation, packaging and handling process.

Accordingly, the presence of Salmonella as enteropathogens in imported fish may reflect the unsatisfactory hygienic conditions during handling, packaging and marketing of the fish. Serological identification of the obtained Salmonella isolates was tabulated in Table 2. It reflected that Sal. enteritidis (1) $2 \%$ and Sal. haifa (2) 4\% were serologically identified from the examined samples of Basa. On the other hand, Barboni was contaminated by 4 different strains of Salmonella as follow, Sal. enteritidis (1) $2 \%$, S. typhimurium (1) 2\%, S. paratyphi (1) $2 \%$ and Sal. haifa (2) $4 \%$. In addition, Denise was contaminated by 3 different strains of Salmonella as follow, Sal. enteritidis (2) 4\%, S. typhimurium (1) $2 \%$, and S.paratyphi (1)2\%. Lastly, Serotyping of the isolated Salmonella indicated that Sal. enteritidis (1) $2 \%$ and Sal. haifa (1) $2 \%$ were serologically identified from the examined samples of Mackerel.

\section{Shigella}

The illustrated data in Table 4 showed that the incidence of Shigella species in the examined imported fish samples was (13) $26 \%$, (11) 22\%, (14) $28 \%$ and (9) $18 \%$ of the examined samples of Basa, Barboni, Mackerel and Denise, respectively. In addition, the serotyping identification of the recovered isolates Table 3 revealed the examined samples of Basa were contaminated by Shigella flexeneri (4) 8\%, Shigella desenteriae (5) 10\%, Shigella boydii (2) $4 \%$ and Shigella sennei (2) $4 \%$. Also, Barboni samples were contaminated by Shigella flexeneri (2) $4 \%$, Shigella desenteriae (5) $10 \%$, Shigella boydii (1) $2 \%$ and Shigella sennei (3) 6\%. Furthermore, Barboni samples were contaminated by Shigella flexeneri (2) $4 \%$, Shigella desenteriae (5) $10 \%$, Shigella boydii (1) $2 \%$ and Shigella sennei (3) $6 \%$.
Furthermore, Mackerel samples were contaminated by Shigella flexeneri (6) $12 \%$, Shigella desenteriae (4) $8 \%$, Shigella boydii (3) $6 \%$ and Shigella sennei (1) $2 \%$. Finally, Denise samples were contaminated by Shigella flexeneri (2) $4 \%$, Shigella desenteriae (2) 4\%, Shigella boydii (2) $4 \%$ and Shigella sennei (2) $6 \%$. According to (E.S889/2009) [38] which assumed that frozen fish must be free from Shigella in $25 \mathrm{~g}$. Consequence, these examined fish is unaccepted, on the other hand Ahmed [3] who stated that 15 samples of imported fish were free from Shigella and accepted. Imported Basa fish was contaminated by Shigella $26 \%$, Onyango [7] among 120 imported Basa out of these, 25 (39.7\%) were contaminated by Shigella spp.

Table 4: Incidence of Shigella strains isolated from the examined samples of imported fishes $(n=50)$.

\begin{tabular}{|c|c|c|c|c|c|c|c|c|}
\hline \multirow[t]{2}{*}{ Shigella strains } & \multicolumn{2}{|c|}{ Basa } & \multicolumn{2}{|c|}{ Barboni } & \multicolumn{2}{|c|}{ Mackerel } & \multicolumn{2}{|c|}{ Denise } \\
\hline & No. & $\%$ & No. & $\%$ & No. & $\%$ & No. & $\%$ \\
\hline Shigella flexeneri & 4 & 8 & 2 & 4 & 6 & 12 & 2 & 4 \\
\hline $\begin{array}{c}\text { Shigella } \\
\text { desenteriae }\end{array}$ & 5 & 10 & 5 & 10 & 4 & 8 & 2 & 4 \\
\hline Shigella boydii & 2 & 4 & 1 & 2 & 3 & 6 & 2 & 4 \\
\hline Shigella sennei & 2 & 4 & 3 & 6 & 1 & 2 & 3 & 6 \\
\hline Total & 13 & 26 & 11 & 22 & 14 & 28 & 9 & 18 \\
\hline
\end{tabular}

\section{Yersinia}

Table 5: Incidence of Yersinia strains Isolated from the examined samples of imported fish $(\mathrm{No}=50)$.

\begin{tabular}{|c|c|c|c|c|c|c|c|c|}
\hline & \multicolumn{2}{|c|}{ Basa } & \multicolumn{2}{c|}{ Barboni } & \multicolumn{2}{c|}{ Mackerel } & \multicolumn{2}{c|}{ Denise } \\
\hline & No. & $\%$ & No. & $\%$ & No. & $\%$ & No. & $\%$ \\
\hline $\begin{array}{c}\text { Yersinia } \\
\text { enterocolitice }\end{array}$ & 14 & 28 & 9 & 18 & 6 & 12 & 9 & 18 \\
\hline $\begin{array}{c}\text { Yersinia } \\
\text { frederiksenii }\end{array}$ & 7 & 14 & 8 & 16 & 5 & 10 & 6 & 12 \\
\hline $\begin{array}{c}\text { Yersinia ruckeri } \\
\text { Yersinia intermedia }\end{array}$ & - & - & 3 & 6 & 3 & 6 & - & - \\
\hline Total & 23 & 46 & 21 & 42 & 18 & 36 & 16 & 32 \\
\hline
\end{tabular}

The illustrated data in Table 3 described Incidence of Yarsinia which was (23) 46\%, (21) 42\%, (18) 36\% and (16) $32 \%$ of the examined samples of Basa, Barboni, Mackerel and Denise, respectively. In addition, the serotyping identification of the recovered isolates (Table 5) revealed the incidence of different strains of Yarsinia as follow, the examined samples of Basa contaminated by were Yarsinia enterocolitice (14) 28\%, Yarsinia frederiksenii (7) 14\%, Yarsinia ruckeri (2) 4\% and Yarsinia intermedia 0\%. Also, Barboni samples contaminated were Yarsinia enterocolitice (9) 18\%, Yarsinia frederiksenii (8) 16\%, Yarsinia ruckeri (1) 2\% and Yarsinia intermedia (3) 6\%. Furthermore, Mackerel samples were Yarsinia enterocolitice (6) 
12\%, Yarsinia frederiksenii (5) 10\%, Yarsinia ruckeri (4) 8\% and Yarsinia intermedia (3) 6\%. Finally, Denise samples were Yarsinia enterocolitice (9) 18\%, Yarsinia frederiksenii (6) 12\%, and Yarsinia ruckeri (1) 2\%. El-Leboudi [8] examined 15 imported fish samples, the author isolated 2 of Yersinia enterocolitica strains $(13.3 \%)$ from imported fish. It is of great concern to record that $Y$. enterocolitica was one of human pathogens that can grow at refrigeration temperature and its presence in food constitutes a public health hazard. In this respect, $Y$. enterocolitica has been implicated in several outbreaks of food illness during the past 20 years in numerous countries all over the world [37].

\section{Vibrio spp}

$V$. cholera has long been known to be responsible for the life threatening secretary diarrhea termed as Asiatic cholera or epidemic cholera Ryan \& Ray [38]. The illustrated data in Table 3 explained the incidence of Vibrio spp was (15) 30\%, (14) 28\%, (13) $26 \%$ and (11) $22 \%$ of the examined samples of Basa, Barboni, Mackerel and Denise, respectively. In addition, the serological identification of the recovered isolates (Table 4) showed the incidence of different strains of Vibrio as follow, the examined samples of Basa contaminated by Vibrio parahaemolyticus were (11) $22 \%$ and (4) $8 \%$ for Vibrio cholera. Also, Barboni samples contaminated were Vibrio parahaemolyticus were (13) $26 \%$ and (1) $2 \%$ for Vibrio cholera. Furthermore, Mackerel samples were Vibrio parahaemolyticus were (11) $22 \%$ and (2) $4 \%$ for Vibrio cholera. Finally, Denise samples were Vibrio parahaemolyticus were (8) 16\% and (3) 6\% for Vibrio cholera. Egyptian standards (E.S889/2009) [32] of frozen fish stated that fish must be free from V. parahaemolyticus. V. parahaemolyticus was previously isolated from imported fish by Abdelnoor \& Roumani [39], Binta et al. [ 40] and Harydi [9].

\section{Aeromonas hydrophilia}

Table 6: Incidence of Vibrio strains Isolated from the examined samples of imported fish $(\mathrm{No}=50)$.

\begin{tabular}{|c|c|c|c|c|c|c|c|c|}
\hline & \multicolumn{2}{|c|}{ Basa } & \multicolumn{2}{c|}{ Barboni } & \multicolumn{2}{c|}{ Mackerel } & \multicolumn{2}{c|}{ Denise } \\
\hline & No. & $\%$ & No. & $\%$ & No. & $\%$ & No. & $\%$ \\
\hline $\begin{array}{c}\text { Vibrio } \\
\text { parahaemolyticus }\end{array}$ & 11 & 22 & 13 & 26 & 11 & 22 & 8 & 16 \\
\hline Vibrio cholera & 4 & 8 & 1 & 2 & 2 & 4 & 3 & 6 \\
\hline Total & 15 & 30 & 14 & 28 & 13 & 26 & 11 & 22 \\
\hline
\end{tabular}

The illustrated data in Table 6 incidence of Aeromonas hydrophilia was (8) 16\%, (11) $22 \%$, (8) $16 \%$ and (6) $12 \%$ of the examined samples of Basa, Barboni, Mackerel and Denise, respectively. Also, Aeromonas hydrophilia founded in frozen imported fish samples by El-Noby [13], Vila et al. \& Farag [11], Sharma [12] and Alzainy [10].

Finally, it is important to mention that the results show that the higher bacterial count (Salmonella) was found in Barboni and gently went down in Mackerel, Basa and Denise, respectively. The higher bacterial count (E. coli) was found in Basa and gently went down in Mackerel, Barboni and Denise, respectively. Moreover, results show that the higher bacterial count (Shigella) was found in Mackerel and gently went down in, Basa, Barboni and Denise, respectively [41,42]. Also, results show that the higher bacterial count (Yarisina) was found in Basa and gently went down in Barboni, Mackerel and Denise, respectively. The higher bacterial count (Vibro spp) was found in Basa and gently went down in Barboni, Mackerel and Denise, respectively. Finally, the higher bacterial count (Aeromonas hydrphilie) was found in Barboni and gently went down in, (Basa and Mackerel) and Denise, respectively. To sum up, it is obvious that Denise spp. was the lowest contaminated imported fish for all kind of examined Enteropathogens. On the opposite, Basa was the most contaminated spp. of imported fish, except contamination by Salmonella it is clear that Barboni and mackerel higher than Basa. Accordingly, the consumption of such contaminated imported fish may, at times, induce public health hazard. The obtained results in the current work, clarified that imported fish possess a higher number of enteric pathogens with significant public health risk. These results may be attributed to unsanitary conditions, cross contamination, fecal pollution and bad personal hygiene conditions during handling, storage, distribution and selling.

\section{References}

1. Singh BR, Kulshrestha SB (1994) Prevalence of Shigella dysentriae group A type in freshwater fishes and seafood. J Food Sci Technol 30 (1): 52-53.

2. Edris AM (2006) Studies on imported fish and fish products, PhD thesis, fac Vet Med, Banha University, Egypt.

3. Ahmed ALF (2006) Improvement of The Bacteriological Quality of Fish Fillets and Peeled Prawn Available in The Egyptian Markets, PhD thesis, fac Vet Med, Cairo University, Egypt.

4. Khadega GH (2014) Microbiological quality of imported fish in Cairo governorate PhD Thesis, Fac. Vet. Alexandria University, Egypt.

5. Elhadi N (2014) Prevalence and antimicrobial resistance of Salmonella spp in raw retail froze imported freshwater fish to Eastern Province of Saudi Arabia. Asian Pac J Trop Biomed 4(3): 234-238.

6. Morris GK, Martin WT, Shelton WH, Wells JG, Brochman PS (1970) Salmonella in fishmeal plants, relative amount of contamination at various stages of processing and method of control Appl Microbiol 19: 401.

7. Onyango DM (2009) Isolation of Salmonella and Shigella from imported fish in Winam Gulf of Lake Victoria. Kenya J Infect Dev Ctries 3(2): 99104.

8. El-Leboudi HS (1991) Yersinia enterocolitica in shell fishes. MV.Sc Thesis Fac Vet Cairo University, Egypt.

9. Harydi AM (2010): Quality evaluation of the imported frozen fish's consignment. M.V.Sc. Thesis, Fac Vet Med Suez Canal university, Egypt.

10. Alzainy ZA (2011) The Occurrence, Hemolytic, Cytotoxic Activity and Antibiotic Susceptibility of Aeromonas hydrophila Isolated from Fish. The Iraqi J Vet Med 35(2): 123-135.

11. Farag AL (2006) Improvement of the bacteriological quality of fish fillets and peeled prawn available in the Egyptian markets. M. V. Sc. Thesis, Fac Vet Med Alexandria University, Egypt. 
12. Sharma IK, Kumar A (2011) Occurrences of enterotoxigenic Aeromonas species in foods of animal origin in North East India. Eur Rev Med Pharmacol Sci 15(8): 883-887.

13. El-Noby NA (2002) Psychrotrophic bacteria in marketed fish. M V Sc. Thesis, Fac Vet Med Zagazig University, Egypt.

14. APHA (American Public Health Association) (1985) Standard methods for examination of Dairy products. $13^{\text {th }}$ Edn., Hausher, WJ., Washington, DC 657-664.

15. Rappaport F, Konforti N, Navon B (1956) New enrichment medium for certain Salmonella. J Clin Path 9: 261.

16. Harvey RW, Price TH (1981) Comparison of Selenite F Muller Kauffman tetrathionate and Rappaport's medium for Salmonella isolation from chicken giblets and after pre-enrichment in buffered peptone water. J Hyg Camp 87(2): 219-224.

17. Collins C, Lyne P , Grange J (1991) Microbiological methods $6^{\text {th }}$ Edn, Microbiology Laboratory Manual, British Library, Butterworth Inc, London, UK

18. Cruickshank R, Dugid JP, Marmion BP, Swain RHA (1975) Medical Microbiology. In. (12 $2^{\text {th }}$ Edn), Churchill Livingstone, Edinburgh, London and New York.

19. Simmon JS (1926) A culture medium for differentiation organisms of the typhoid- aerogenes groups and the isolation of certain fungi. J Infect Dis 39(3): 209-214.

20. Kovacs N (1978) A simplified method for detection indol formation by bacteria. 2 immunitats forsch 56: 311-313.

21. Ljutov V (1963) Technique of voges-proskauar test. Actapathol Microbial Scaned.

22. Mac Faddin JF (1976) Biochemical tests for identification of medical bacteria. The Williams and Wilkin, INC, Baltimore, Md. USA.

23. Hugh R, Lelfson E (1953) The taxonomic significance of fermentative verus oxidative metabolism of carbohydrate by various gram negative bacteria. J Bacteriol 66(1): 24-26.

24. Edwards PR, Ewing WH (1972) Identification of Enterobacteriaceae, ( $3^{\text {rd }}$ Edn). Minneapolis, Burgess Publishing Pp. 145

25. Kauffman F (1974) Kauffman white scheme WHO-BD 172, h, Rev. 1. Acta path Microbial Scand 61: 385.

26. International Commission on Microbiological Specification for Foods "ICMSF" (1996) Micro-organisms in foods. 1. Their significance and methods of enumeration. ( ${ }^{\text {rd }}$ Edn). Toronto, University of Toronto Press.

27. Schiemann DA (1983) Comparison of enrichment and plating media for recovery of virulent strain of Yersinia enterocolitica from inoculated beef stew. J Food Protec 46: 957-964.

28. Krieg AG, Holt VB (1984) Food Borne zoonosis due to fish consumption. Japan Sci Fish 68(5): 436-442.

29. MacConkey (1908) Bile Salt Media and their advantages in some Bacteriological Examinations. J Hyg 8(3): 322-324.

30. APHA (American Public Health Association) (1992) Standard methods for examination of Dairy products. $\left(13^{\text {th }} \mathrm{Edn}\right)$, Hausher WJ, Washington, DC Aquaculture Report No. 937 ISSN 2070-6987, Mangalore, India.

31. Havelaar AH, Pot-Hogeboom WM, Koot W, Pot R (1987) F-specific bacteriophages as indicators of the disinfection efficiency of secondary effluent with ultraviolet radiation. Ozone Science and Engineering 9: 353-368.

32. Feldman D, Ganon J, Hoffman R, Simpson J (2003) The solution for data analysis and presentation graphics ( $2^{\text {nd }}$ Edn). Abacus Lancripts, Inc., Berkeley, USA.

33. E.S 889/2009: Egyptian Standards, Frozen fish, part one for whole fish, included different types of imported fish.

34. Donenberg M, Kaper J (1992) Enteropathogenic E. coli infection and immunity, Appl Microbiol 60: 3953

35. Stevens S, Shimada K, Truper H (1989) Epidemiological investigation of Salmonella in fish. Appl Environ Microbiol 55(2): 331-336.

36. Baquar W, Heinann P, Linger M (1994) Salmonella contamination in fishes. Archiv Fur Lebensmittel Hygiene 45(3): 213-217.

37. Dalsgaard A (1998) The occurrence of human pathogenic Vibrio spp. And Salmonella in aquaculture. Inter J Food Sci Technol 33: 127-138.

38. International Commission on Microbiological Specification for Foods "ICMSF" (1998) Micro-organisms in foods. Microbial Ecology of food commodities. Blackie Academic and professional, London, New York, Tokyo, Melbourne, Madras.

39. Ryan G, Ray B (2004) Role of aerobic intestinal pathogens of flesh water fish in transmission of human disease. J Prot 55(9): 739-740.

40. Abdelnoor AM, Roumani BM (1980) Characterization of some Vibrio parahaemolyticus strains isolated from seafoods in Lebanon. Zentralbl Bakteriol (B) 170(5-7): 502-507.

41. Binta MG, Nyaga PN, Tjaberg TB, Valland M (1982) Vibrio parahaemolyticus occurance in marine seafish, shellfish, water and sediment in Kenya. J Hyg 59(7): 442-445

42. Edris AA, Reham A, Amin Marionette Z, Naseif Ebtsam M, Abdel Fatah (2014) Evaluation of Retiled Salted Fish according to Egyptian Standard. Benha Vet Medical J 27 (2): 168-176.

\section{Your next submission with Juniper Publishers} will reach you the below assets

- Quality Editorial service

- Swift Peer Review

- Reprints availability

- E-prints ServiceManuscript Podcast for convenient understanding

- Global attainment for your research

- Manuscript accessibility in different formats

( Pdf, E-pub, Full Text, Audio)

- Unceasing customer service

Track the below URL for one-step submission https://juniperpublishers.com/online-submission.php 